\title{
Tour de Force: \\ Irina and Dmitrii Guzevich's Analytical Bibliography of Tsar Peter's Grand Embassy to Europe
}

\author{
Ernest A. Zitser \\ Duke University \\ ernest.zitser@duke.edu
}

Guzevich, D. IU, and I. D. Guzevich. Pervoe evropeřskoe puteshestvie tšàriā Petra: analiticheskaiā bibliografiiā za tri stoletiiâ, 1697-2006 [Tsar Peter's First European Trip: An Analytical Bibliography Covering Three Centuries, 1697-2006]. Emmanuel Waegemans, ed. Sankt-Peterburg: Dmitrĭ Bulanin, 2008. 907 p. ISBN: 5860075820 .

The book under review is an analytical bibliography about a very specific, and seemingly very narrow "historical subject" (istoricheskii siuzhet): Tsar Peter Alekseevich Romanov's one-and-a-half-year Grand Embassy to northern and central Europe (16971698), the first trip abroad by a Muscovite monarch since Peter's father (Tsar Aleksei Mikhailovich) accompanied his troops to the Polish-Lithuanian border during the Thirteen Years' War (1654-1667). This specialized bibliography was compiled by Dmitrii Iur'evich (1955-) and Irina Dmitrievna Guzevich (1953-), a husband-and-wife team of Russian-born historians of science and technology who now reside in France. ${ }^{1}$ The Guzevich bibliography includes citations to an incredibly-diverse source base: scholarly monographs; dissertations and avtoreferaty; journal, magazine, and newspaper articles; book reviews; belles-lettres; popular and polemical works; visual materials (portraits, engravings, postcards, comic strips); flyers and ads; as well as entries in encyclopedias and other reference works, in 26 different languages (p. 31). ${ }^{2}$ According to the authors, there are actually over 5.5 thousand published works on the subject (p. 7), a figure that does not include foreign language newspaper articles contemporary with Peter's first European tour, a bibliography of which the Guzeviches hope to publish in a separate volume (p.

\footnotetext{
1 "Guzevich, Dmitrii Iur'evich" and "Guzevich (urozhd. Dolinskaia), Irina Davidovna," in Rossiiskoe zarubezh'e vo Frantsii 1919-200o: biograficheskii slovar' v trekh tomakh, pod obshchei redaktsiei L. Mnukhina, M. Avril', V. Losskoi (Moskva: Nauka, 2008-), 1: 440-1. D.Iu. Guzevich currently works as a librarian at the Bibliothèque du Centre d'études des mondes russe, caucasien et centre-européen. La bibliothèque du CERCEC, École des Hautes Études en Sciences Sociales (last consulted 12 August 2013). I. D. Gouzevich is affiliated with both the Centre Alexandre Koyré, École des Hautes Études en Sciences Sociales (EHESS) and the Centre Maurice Halbwachs, Ecole Normale Supérieure. IdRef: les référentiels Sudoc (last consulted 12 August 2013).

${ }^{2}$ The bibliography includes works written in (or translated from) the following languages (listed in Russian alphabetical order): English, Belarusian, Bulgarian, Hungarian, Dutch, Greek, Georgian, Danish, Spanish, Italian, Latin, Latvian, German, Norwegian, Polish, Portuguese, Romanian, Russian, Serbian, Turkish, Ukrainian, Finnish, French, Croatian, Czech, and Swedish. The authors also mention the existence of relevant texts in Slovak, Slovene, Lithuanian, Moldavian, and Estonian languages (p. 31n.52).
} 
907). A large number of the publications included in the Guzevich bibliography appeared at the turn of the twenty-first century in article collections and published proceedings of conferences organized during the course of a whole series of jubilees connected with the Petrine reforms, including the tercentenary of the founding of St. Petersburg (pp. 8-9, 906-7). In that sense, this publication constitutes the most up-to-date Petrine bibliography currently available.

The amount of material published on Peter's Grand Embassy demonstrates the widely-perceived importance of the tsar's ambitious undertaking, as well as its as-yetunresolved status within Russian historiography. The Guzevich bibliography is an attempt both to catalog the various statements on the topic and to correct them. In the 2008 monograph that was issued by the Institute of Peter the Great alongside, and as a complement to their annotated bibliography, ${ }^{3}$ the authors argue that Peter's Grand Embassy was not just a "typical, Asiatic, diplomatic caravan." ${ }^{4}$ Nor was it some kind of wild shopping spree of a semi-"barbaric" prince obsessed by all things "Western." It was, rather, a specific instance of what the Guzeviches (adopting the terminology used by other historians of science and technology) call "knowledge transfer," that is, the deliberate appropriation and selective assimilation of specific tools, artifacts, and ideas by concrete historical agents from the European periphery. ${ }^{6}$ According to the authors, the

\footnotetext{
3 D.Iu. Guzevich and I. D. Guzevich, Velikoe posol'stvo: rubezh epokh, ili nachalo puti, 1697-1698. 2., rasshirennoe i ispr. izd. (Sankt-Peterburg : Dmitriĭ Bulanin, 2008). This book, which serves as the second tome of the two-volume publication issued by the Institute of Peter the Great, represents the "second, expanded, and corrected edition" of the 2003 monograph published with the support of the St. Petersburg city government's Press and Public Relations Committee (komitet po pechati $i$ sviaziam $s$ obshchestvennost'iu Administratsii Sankt-Peterburga) in the series "Peterburg's Roots": D.Iu. Guzevich and I. D. Guzevich, Velikoe posol'stvo [Korni Peterburga] (Sankt-Peterburg: Mezhdunarodnyi fond spasenia Peterburga-Leningrada; "Feniks", 2003). See Velikoe posol'stvo--rubezh epokh, ili nachalo puti (28 December 2008) and Prezentatsiia programmy 'Put' Petra Velikogo' i knig o Velikom posol'stve (17 February 2009), Fond D. S. Likhacheva (last consulted 12 August 2013).

${ }^{4}$ The phrase in quotes is taken from E. V. Anisimov's introduction to the 2003 edition of the Guzevich monograph. E. V. Anisimov, "Znanie-sila, ili Petr I v poiskhakh novoi Rossii," in Velikoe posol'stvo [Korni Peterburga], 5-12, here 5 .

5 "In the rapid transfer of European knowledge to Russia, the role of Peter I has been likened to a savage visiting a supermarket who, fascinated by the riches on display, shovels everything into his basket without knowing whether he needs it or not." Irina Gouzévitch and Dmitri Gouzévitch, "Introducing Mathematics, Building an Empire: Russia under Peter I," The Oxford Handbook of the History of Mathematics, edited by Eleanor Robson and Jacqueline Stedall [Oxford handbooks] (Oxford; New York: Oxford University Press, 2009), 353-74, here 354. Cf. Janet M. Hartley, "England 'Enjoys the Spectacle of a Northern Barbarian': The Reception of Peter I and Alexander I," in A Window on Russia: Papers from the V International Conference of the Study Group on Eighteenth-Century Russia, edited by Maria Di Salvo and Lindsey Hughes (Rome: La Fenice, 1996), 11-18.

${ }^{6}$ Irina Gouzévitch, Le transfert du savoir technique et scientifique et la construction de l'Etat Russe (fin du XVe-début du XiXe siècles. 2 vols. Thèse de doctorat en histoire des techniques (Paris: Université Paris VIII, 2001); eadem, "Le transfert du savoir technique et scientifique et la construction de l'Etat russe: extraits de la thèse soutenue pour obtenir le grade de docteur de l'Université," SABIX: Bulletin de la Société des Amis de la Bibliothèque de l'Ecole polytechnique, 33 (May 2003), 1-154; eadem, "Le transfert technique et ses avatars: le cas de la Russie," Documents pour l'histoire des techniques 14 (October 2007), 14-23, here 16-17, citing the work of R. G. A. Dolby, "The Transmission of Science," History of Science 15 (1977), 1-43. For a more recent
} 
transplantation and (eventual) institutionalization of these foreign-inspired innovations is precisely what made it possible for Tsar Peter Alekseevich and his supporters to carry out the military, financial, and administrative reforms that transformed Muscovy into Imperial Russia. In other words, without the "Grand Embassy" there would be no "Great Northern War" and no "Emperor Peter I, the Great." And there would almost certainly be no "St. Petersburg." Although the Guzeviches are not the first scholars to stress the "educational" value of the tsar's Grand Embassy, ${ }^{7}$ the level of detail provided by the authors allows them to make a convincing case for the wider, historical significance of Peter's first trip to Europe, which, from their perspective, appears as the most important "informational breakthrough on the western European-Russian axis" since the reign of Ivan III. ${ }^{8}$

Despite the obvious ideological agendas of the book's institutional sponsors, both foreign and domestic, ${ }^{9}$ the authors of the bibliography mount a concerted (and largely successful $)^{10}$ effort to remain above the fray of contemporary debates about Russia's

review of the literature, see Kostas Gavroglu, et. al., "Science and Technology in the European Periphery: Some Historiographical Reflections," History of Science 46 (2008), 153-175.

${ }^{7}$ This point was made in Anisimov's introduction to, and reiterated in the reviews of the Guzeviches' 2003 monograph. Anisimov, "Znanie-sila," op. cit., 7; Emmanuel Waegemans, Review: Velikoe posol'stvo / Guzevic, D. \& I. (Sankt-Peterburg, 2003), in Ab imperio 4 (2004), 702-8, here 703-4. See also Michael Schippan, Review: Velikoe Posol'stvo [Die Große Gesandtschaft]. Korni Peterburga by Dmitrij Ju. Guzevič; Irina D. Guzevič, in Jahrbücher für Geschichte Osteuropas, Neue Folge, Bd. 56, H. 2 (2008), 289-29o.

${ }^{8}$ Dmitri Gouzévitch, La Grande Ambassade (1697-1698) comme percée informationnelle sur l'axe Europe occidentale-Russie. Diplôme d'études approfondies (DEA) en histoire et civilisations (Paris: École des hautes études en sciences sociales, 200o).

${ }^{9}$ The Guzevich bibliography constitutes the very first publication of the Institute of Peter the Great (IPG), a non-profit cultural organization that was founded in 2010 under the auspices of the St. Petersburg City Council's Institute of Cultural Programs in order to promote "the study and advance the legacy of Peter the Great in the spheres of culture, education, and the humanities." By Peter's "legacy" the IPG's website means "the sum total of ideas and traditions confirming Russia's European choice, its commitment to the principles of the European Enlightenment and of cultural commonality, while preserving the national identity of Russia as a great nation." IPG seeks to accomplish this ambitious, if somewhat vague and selfcontradictory goal by means of an active education, conference, and publication program, as well as through such projects as the digital "Collection of Petrine Monuments of Russia and Europe." In this way, IPG seeks to extend beyond Russian borders the kind of scholarly cooperation and cultural exchanges sponsored by the D. S. Likhachev Fund's "Byways of Peter the Great," a cultural program that initially sought "to promote the cultural integration of small and large Russian cities, which are either obliged to Peter I for their foundation or are historically linked to his activity." This approach, in turn, parallels, and seeks to tap into a renewed interest on the part of some foreign sponsors in furthering scholarship that integrates Russia into a larger, international framework. Indeed, as the editor's "Forward" points out (5-6), the publication of this analytical bibliography was made possible not only by the Guzeviches' personal and professional contacts in Russia, but also in northern Europe. Bibliografiia rabot o Velikom posol'stve (28 November 2008), Fond im. D. S. Likhacheva (last consulted 12 August 2013); Institut Petra Velikogo, Institut kul'turnykh program, St. Peterburg (last consulted 12 August 2013); Put' Petra Velikogo, Fond im. D. S. Likhacheva (last consulted 12 August 2013).

${ }^{10}$ I say "largely successful" because, as Irina Guzevich perceptively notes, the focus on what the tsar learned during his Grand Embassy to Europe unintentionally over-emphasizes both the non-Russian sources of Peter's innovations and the radical nature of his break with the Muscovite past. "To the extent that [my dissertation] focused on the transfer of Western knowledge to Russia, my attention was centered on those areas where such knowledge was solicited because it was missing in the host country. Following the trail of 
Sonderweg." They do so, in large part, thanks to the "fact-centered" methodology (faktologiia) that they employ in analyzing their data set, viz., the 5,238 bibliographic entries that they collected and examined (mostly de visu) in the course of their research into the history of the Grand Embassy (p. 907, 107-111). As the Guzeviches observe in the introduction to the bibliography, political imperatives, scholarly interpretations, and popular attitudes towards Russia's reforming tsar have undergone many changes during the three hundred years since Peter embarked on his first European tour. Over that period, only one thing has remained the same, and of enduring scholarly value: "His Highness the Fact" (Ego Vysochestvo Fakt) (p. 106). The authors' unswerving commitment to scientific objectivity and to the fundamental distinction between "facts" and "artifacts" is crucial for understanding both their overall conception of what constitutes an "analytical" or "critical" bibliography and their reasons for writing in this particular genre. ${ }^{12}$

According to the authors, historical events, much like natural and social processes that produce them, are not mere "artifacts," that is, they cannot be "made or modified by human workmanship" ex post facto. Instead, past events constitute interlocking links in amazingly complex chains of causality that we somewhat simplistically (and reductively) refer to as "facts." Such events often leave more-or-less observable material traces in the historical record. The correct interpretation of these traces is the most basic and primary job of the professional historian, regardless of whether s/he is essentially an "archivist" ("archival rat" or "bookworm") or an "analyst" (speculative theorist) (pp. 29-30). The authors acknowledge and, indeed, welcome the possibility that new archival discoveries or the use of different methods and tools may lead to a revision of currently-accepted interpretations. But they also point out that new evidence may frequently be found in

European contributions, I was led to evoke the context that made them appealing and to see their pioneering and challenging nature (caractère pionnier et stimulant). Despite my best efforts at objectivity, this approach (démarche) might, at times, give the impression of a catastrophic vision of someone obsessed with the complex of Russian poverty and European performance (vision catastrophiste de quelqu'un obsédé par le complexe de la pauvreté russe et de la performance européenne)." Guzevich's proposed solution is to relativize the very notion of European "performance" and to focus on "the perception of Europe historically established by the Russians." According to the author, Russia's "myth of a dynamic and technologically [superior] Europe," which was born in 17th century Muscovy, nourished Peter's imagination and incited him to see the West for himself. Irina Gouzévitch, "Le transfert technique et ses avatars: le cas de la Russie," 223.

${ }^{11}$ The role of Peter the Great in launching Russia on its "special path" to modernity has received renewed emphasis after the collapse of the Soviet Union. Ernest A. Zitser, "Post-Soviet Peter: New Histories of the Late Muscovite and Early Imperial Russian Court", Kritika: Explorations in Russian and Eurasian History 6:2 (Spring 2005), 375-92.

${ }^{12}$ Like "historical, textual, and descriptive bibliographies," to which this genre is related, the analytical bibliography is "a specialty within library and humanistic spheres that studies the book and all its parts in the assumption that any individual book is a representation of the society in which it was produced and that analyzing aggregates of books will assist in understanding the means and circumstances of transmitting ideas and the general nature of past society." Richard Cox, American Archival Analysis: The Recent Development of the Archival Profession in the United States (Metuchen, N.J.: Scarecrow Press, 1990), 262, available online at: http://www2.archivists.org/glossary/terms/a/analytical-bibliography (last consulted 12 August 2013). 
previously published sources. This is why the authors repeatedly caution against the excessive "fetishization" of archives and the danger of "reinventing the wheel" (p. 7, 31). But most of all, the authors are concerned about the circulation of "artifacts" (artefakty), that is of "spurious results, effects, or findings in a scientific experiment or investigation, esp. ones created by the experimental technique or procedure itself."13 Citing P. N. Miliukov, the Guzeviches argue that the task of the professional historian is not to sit in judgment about the "positive or negative aspects of past events, but to serve as an expert" and impartial witness, "i.e. to weigh the reliability" of all the available evidence (p. 13). In the case of a well-researched topic such as Peter's Grand Embassy, that task is made easier by the existence of reference works (like the one under review) that allow researchers to assess the degree to which the work published by a particular scholar approximates the true facts of the case at any particular point in time. From this perspective, an "analytical bibliography" is nothing less than "a mirror of professionalism" (p. 7).

Unfortunately, the Guzevichs argue, the professionalism of most of the individuals who published works on the subject in question over the course of the last three centuries-"not only professional and amateur historians, but also linguists, art historians, philosophers, publicists, politicians, journalists, litterateurs, authors of comic books, writers of commercials, artists, sculptors, engravers, composers, [as well as] figures of cinema and the theater" (p. 113) - leaves much to be desired. "Even professional historians [...] demonstrate an extremely weak familiarity with the auxiliary (specialized) historical disciplines" or else "display an extreme negligence or inattention" to such fields as "historical geography, nomenclature and titulature, as well as the related [fields] of historical onomastics, historical chronology, historical metrology, genealogy, numismatics, and faleristics, the study of uniforms (uniformistika), source criticism, etc., not to mention such fields of knowledge as the history of science, technology, [and] medicine (history of scientific and educational institutions, history of tool- and shipbuilding)." (p. 114). Overall, the authors' "experience of working on the history of the Grand Embassy [...] demonstrated that the historical literature on the topic (not only popular, but also academic), is remarkably littered (zasorena) with artifacts, unchecked assertions, and repeated misspellings" (p. 31). These are precisely the kind of "factological" and "terminological" errors (p. 106) that the authors of the bibliography note for each and every entry in the book (including for their own publications, pp. 415418). These annotations, which in "clinical" cases (p. 106), sometimes run into several pages of critical comments, constitute the bulk of the bibliography (pp. 132-817). One hundred-and-one of the most common "mistakes in the historiography of the Grand Embassy"-viz., those that are repeated in at least two or three separate publications-are singled out for special, extended treatment (pp. 33-106) by the authors. ${ }^{14}$

\footnotetext{
13 "artefact | artifact, n. and adj." OED Online. June 2013. Oxford University Press (accessed August 16, 2013). Compare the definitions provided by the Словари и энциклопедии на Академике (accessed August 16, 2013).

${ }^{14}$ This section of the bibliography is reprinted as an appendix to the 2008 monograph. See "Oshibki v istoriografii o Velikom posol'stve," Velikoe posol'stvo, 451-498 (Prilozhenie 13).
} 
The results of this "factological" analysis reveal that, in reality, "many of the problems" that have plagued the historiography of the Grand Embassy "have long been resolved." ${ }^{15}$ And now that the Guzevich bibliography has made it possible for researchers to identify and compare most of the published texts on the subject, it becomes easier to determine what particular aspects must still be sought out in the archives. Unfortunately, actually using this bibliography is not as intuitive as this reader might have hoped. One of the major problems facing any bibliographer is how to arrange a large amount of information in a way which will aid scholarly research. ${ }^{16}$ Basically, there are two incompatible solutions to the problem: a simple alphabetical listing (such as the one adopted by the Guzeviches) or a classified list. The former has the advantage of being simple and easy to use. It is especially useful for quick reference: if the student or researcher wants to use this bibliography to compile a list of an individual scholar's contributions to Petrine studies, or needs a simple check of the accuracy of his or her citations, it is ideal. However, it is less helpful when a student or researcher wants to use a bibliography as an aid to a more complex task, such as writing a paper. What $\mathrm{s} / \mathrm{he}$ needs then is a guide to appropriate reading. If, for example, a graduate student has to write a paper giving a general overview of the field of museology during the reign of Peter the Great, s/he will need to compile a very different reading list from the one $\mathrm{s} /$ he would compile if the paper were to be written on a theoretical subject such as the relationship between Peter's Kunstkamera and European cabinets of curiosities, or were to be a case study about a specific museum collection acquired during the course of, or as a result of Peter's Grand Embassy. In this case, it is more useful if a bibliography recognizes, and is arranged to suit these needs (e.g. by providing a reference to "Kunstkamera").

Of course, there can be no "right" way to arrange a bibliography: what is helpful in one work-context will be less helpful in another. That being said, the second option outlined above seems most "user-friendly" to students and researchers. It would have been very helpful if, in addition to the name index and a chronological index of publications, the Guzeviches had included a subject index, either based on the most common terms or topics that come up in the study of the Grand Embassy ${ }^{17}$ or on the type

\footnotetext{
${ }^{15}$ According to the authors of the analytical bibliography under review, the dating and attribution of the famous painting of "Captain Marko Martinović Teaching Navigation to Russian Boyars [sic]" (Perast City Museum, Montenegro) provides a great example of the "utility of reading" widely in foreign secondary sources. In the 1960s, the re-discovery of an 1842 Croatian article that had originally been published in a Hungarian newspaper allowed Yugoslav scholars to re-date the painting to 1711 and to attribute it to an asyet-unidentified Venetian artist. Yet Soviet scholars of Russian-Balkan relations continued to treat this painting as contemporaneous with the Muscovite chamberlains' visit to Perast in 1698. (p. 31-2n.53).

${ }^{16}$ The discussion in this and the following paragraphs is indebted to the approach advocated in the introduction to Gillian Bennett and Paul Smith, Contemporary Legend: A Folklore Bibliography [Garland folklore bibliographies, vol. 18] (New York: Garland, 1993), xxi-xxii.

${ }^{17}$ Works included in the Guzevich bibliography deal with the following four subjects:(1) the Grand Embassy itself; (2) individuals, both Russians directly involved with the Grand Embassy and foreigners who entered Russian service during this period; (3) direct consequences (posledstviia) of the Grand Embassy (esp. a series of decrees, connected with the participants' European impressions); and (4) specific events, phenomena or objects, directly connected with the Grand Embassy, including those that constitute its direct or proximate consequences or those that had influenced it ( $v$ tom chisle iavliavshikhsia ego priamymi $i$ blizhaishimi sledstviiami ili okazyvavshikh na nego vliianie). (p. 32). Among the last two groups of subjects
} 
of work a student or scholar might undertake. In the latter case, citations might have been organized into four basic groupings: (1) texts that might be useful in all or most kinds of research and writing; (2) descriptive overviews of the field written with the beginner or general reader in mind; (3) case studies and discussions of theoretical or technical issues written for the specialist reader; and (4) reference works and collections of primary sources. ${ }^{18}$ As it now stands, the scholar who wishes to use the Guzevich bibliography as a guide to appropriate reading must come up with his or her own workaround strategies, which might include consulting the table of contents of the authors' 2008 monograph, the second tome of the two-volume publication issued by the Institute of Peter the Great. Unfortunately, the fact that the annotated bibliography and the monograph appeared in very limited press runs means that this option will only be available to the users of a few, select research libraries. ${ }^{19}$ This will unjustly limit the impact of the Guzeviches' substantial contribution to the fields of Russian history and Slavic bibliography. To avoid this undeserved fate, the present reviewer would urge the authors to add a subject index to the next edition of their analytical bibliography, should there ever be one. Or, better yet, to consider publishing their bibliography on the World Wide Web, preferably in the form of a freely-available, online database or, at the very least, a searchable .pdf file. An updateable, online bibliography of works on the Grand Embassy would constitute a perfect complement to the Institute of Peter the Great's digital "Collection of Petrine Monuments of Russia and Europe." ${ }^{20}$ And it would certainly

the authors include such topics as (a) the Tsykler affair; (b) Muscovite interference in Polish affairs (1696-98 royal election); (c) composition by A. A. Weide of "Military Statutes"; (d) inauguration of the Order of St. Andrew (and myth of Lefort as first cavalier); (e) myth about Peter I as Freemason; (f) change of calendar and appearance of New Year's tree (ëlka); (g) beard-shaving; (h) change of costume; (i) introduction of official, stamped paper (gerbovaia bumaga); (j) changes in bureaucratic paperwork (from stolbtsy to tetradi); (k) creation of the Pharmacy Chancery's medicinal garden (zavedenie Aptekarskogo ogoroda); (l) Archil II's commission of Georgian type-face in Amsterdam (took place in 168 os but affected some actions of Peter and Aleksandr Archilovich during Grand Embassy); (m) the publishing privileges granted to Jan Tessing and the publication activity of Il'ia Kopievskii; (n) the opening of Moscow-based schools of Navigation and Artillery; and finally (o) the Karlowitz Congress. (p. 32-3) This is by no means a full list of the topics covered by the Guzevich bibliography, but it represents a representative selection of the subjects mentioned in the annotations.

${ }^{18}$ The four fundamental source books for the study of the Grand Embassy, for example, are mentioned together only in passing under the entry for E. F. Shmurlo's Sbornik dokumentov, otnosiashchikhsia k istorii tsarstvovaniia Imperatora Petra Velikogo (p. 8o1). The other three major source collections (Pokhodnye zhurnaly, Pis'ma i Bumagi Imperatora Petra Velikogo, Pamiatniki diplomaticheskikh snoshenii) are all listed separately, in alphabetical order. The same goes for previous Petrine bibliographies (Mintzloff, for example, appears under both the foreign language and the Russian-language listings).

${ }^{19}$ As of August 2013, only 25 libraries in WorldCat listed the Guzevich bibliography; only 12 libraries held the second edition of the monograph ( 53 if both the first and second editions of the work are included).

${ }^{20}$ The initial results of this project have appeared in the first volume of a planned three-volume work: Petrovskie pamiatniki Rossii: svod istoricheskikh i memorial'nykh pamiatnikov Rossiiskoi Federatsii petrovskogo vremeni [red.-sost. A. V. Kobak, N. L. Korsakova]. (Sankt-Peterburg: Evropeiskii dom, 2010-); Petrovskie pamiatniki Rossii (9 December 2010), Fond Likhacheva (last consulted 12 August 2013). Dmitrii Guzevich is the person charged with supervising the work devoted to Petrine monuments in Europe: http://spp.lfond.spb.ru/contacts (last consulted 12 August 2013). 
make the Guzeviches' tour de force a much more accessible and user-friendly scholarly resource. 